\title{
Pre-Progastrin-Releasing Peptide
}

National Cancer Institute

\section{Source}

National Cancer Institute. Pre-Progastrin-Releasing Peptide. NCI Thesaurus. Code C113250.

Pre-prog astrin-releasing peptide (148 aa, $16 \mathrm{kDa}$ ) is encoded by the human GRP gene.

This protein is involved in the regulation of both the gastrointestinal and nervous systems. 